\title{
CONFLICT MOBILIZATION IN RUSSIAN SOCIAL MEDIA COMMUNITIES AS AN ACTUAL PRACTICE OF PROTEST COMMUNICATION: COLLECTIVE AND PERSONAL DIMENSION ${ }^{1}$
}

\author{
Marina V. Milovanova \\ Volgograd State University, Volgograd, Russia \\ Elena V. Terentyeva \\ Volgograd State University, Volgograd, Russia
}

\begin{abstract}
From the standpoint of communicative approach conflict mobilization is considered in the article as an actual practice of protest communication in modern Russia. The parameters of the collectivepersonal dimension of conflict mobilization in the most popular social networks among Russian users: VKontakte, Odnoklassniki, Instagram, Twitter, Facebook are presented. Major forms of social group members online participation in protest actions, interaction means of conflict mobilization communities and the formation of Internet solidarity have been characterized with such criteria as publication volume and frequency. Selective factual and emotional-psychological argumentation with elements of defamation of opponents is concluded to prevail in the communicative behavior of the addresser. Frequent implementation of phatic strategy through consolidating appeals to community members with elements of idealization and glorification of protest actors is revealed. The addresser's self-presentation strategy is noted to be applied rather rarely; it is actualized mainly through their identification with the collective position of the group and the mass addressee. It has been established that the addressee is characterized by active self-presentation through the presentation of a subjective position opposed to a mutual opponent, is distinguished by an appeal to ethical and emotional argumentation, a variety of phatic tactics. The article reveals the relevant language means of implementing the identified strategies, shows the features of the text structure of mobilization posts.

Key words: protest communication, strategies, tactics, social networks, network communities, addresser, addressee, Russian.

Citation. Milovanova M.V., Terentyeva E.V. Conflict Mobilization in Russian Social Media Communities As an Actual Practice of Protest Communication: Collective and Personal Dimension. Vestnik Volgogradskogo gosudarstvennogo universiteta. Seriya 2. Yazykoznanie [Science Journal of Volgograd State University. Linguistics], 2021, vol. 20, no. 5, pp. 122-140. (in Russian). DOI: https://doi.org/10.15688/jvolsu2.2021.5.10
\end{abstract}

\section{КОНФЛИКТНАЯ МОБИЛИЗАЦИЯ В СООБЩЕСТВАХ СОЦИАЛЬНЫХ СЕТЕЙ РОССИИ КАК АКТУАЛЬНАЯ ПРАКТИКА ПРОТЕСТНОЙ КОММУНИКАЦИИ: КОЛЛЕКТИВНО-ЛИЧНОСТНОЕ ИЗМЕРЕНИЕ ${ }^{1}$}

\section{Марина Васильевна Милованова}

Волгоградский государственный университет, г. Волгоград, Россия

\section{Елена Витальевна Терентьева}

Волгоградский государственный университет, г. Волгоград, Россия 
Аннотация. Статья посвящена рассмотрению с позиций коммуникативного подхода конфликтной мобилизации как актуальной практики протестной коммуникации современной России. В работе представлены результаты исследования параметров коллективно-личностного измерения конфликтной мобилизации в наиболее популярных среди российских пользователей социальных сетях «ВКонтакте», «Одноклассники», «Инстаграм», «Твиттер», «Фейсбук». Авторами с учетом таких критериев, как объем публикаций, активность их размещения, основные формы онлайн-участия членов социальных групп в протестных акциях охарактеризован инструментарий интеракции сообществ конфликтной мобилизации и формирования интернет-солидарности. Сделан вывод о доминировании в коммуникативном поведении адресанта селективного фактического и эмоционально-психологического аргументирования с элементами диффамации оппонентов; частотной реализации фатической стратегии посредством консолидирующих призывов к членам сообщества с элементами идеализации и героизации акторов протеста; отмечена наименьшая представленность стратегии самопрезентации адресанта, актуализируемая преимущественно через его идентификацию с коллективной позицией группы и массовым адресатом. Установлено, что адресат характеризуется активной самопрезентацией через предъявление частной субъективной позиции, противопоставленной обобщенному оппоненту, обращением к этико-эмоциональной аргументации, разнообразным фатическим тактикам. В статье выявлены релевантные языковые средства реализации установленных стратегий, показаны особенности текстовой структуры мобилизационных постов.

Ключевые слова: протестная коммуникация, стратегии, тактики, социальные сети, сетевые сообщества, адресант, адресат, русский язык.

Цитирование. Милованова М. В., Терентьева Е. В. Конфликтная мобилизация в сообществах социальных сетей России как актуальная практика протестной коммуникации: коллективно-личностное измерение // Вестник Волгоградского государственного университета. Серия 2, Языкознание. - 2021. - Т. 20, № 5 . C. 122-140. - DOI: https://doi.org/10.15688/jvolsu2.2021.5.10

\section{Введение}

Протестные движения в современном обществе представляют собой различные коллективные действия, с помощью которых субъекты формулируют собственную позицию, критическое отношение к существующему положению вещей, а также предлагают решения социальных проблем [Cammaerts, 2012; 2015; Castells, 2009; 2012]. Как правило, протестные движения характеризуются следующими признаками: 1) наличие конфликтного и широкого протестного мобилизационного потенциала; 2) реализация четкого противопоставления в рамках модели «мы / они»; 3) значимость в организации социальных движений; 4) ориентированность на формирование, поддержание и эксплуатацию идеи коллективной идентичности; 5) структурированность посредством плотных неформальных социальных сетей [Della Porta, Diani, 2006; Новые социальные движения..., 2020; Яницкий, 2012].

В научных исследованиях в качестве основной мобилизационной площадки, позволяющей инициировать и синхронизировать конкретные социальные действия потенциальных акторов, рассматриваются сообщества в со- циальных сетях [Шерстобитов, Брянов, 2013]. На таких площадках происходит практически мгновенный обмен контентом, который имеет большое значение для координации протестной активности, в частности, в них передается информация о месте и времени протестной акции, транспорте, присутствии силовых структур, возможном юридическом сопровождении в случае задержания и т. д. Кроме того, сообщества в социальной сети способствуют активному обмену эмоциональной и мотивационной информацией в поддержку протестной деятельности, включая сообщения, выражающие негативные эмоции, социальную идентификацию, групповую эффективность, политические предпочтения.

Инструменты мобилизации в сообществах социальных сетей (далее - соцсети), представленные различными фильтрами, рейтингами, способствуют распространению информации, которая подается и оценивается как исключительно достоверная и являющаяся основанием для коллективного принятия решений и активного (участие в уличной демонстрации, митинге, пикете) либо пассивного (интернет-голосование, репост, лайк, комментарий и т. д.) реагирования. Обмен информацией между членами социальных групп повы- 


\section{МАТЕРИАЛЫ И СООБЩЕНИЯ}

шает ее эффективность в плане расширения мобилизационного участия членов социума в протестной деятельности.

Способы мобилизации членов социальных групп для вовлечения в протестные акции мы классифицируем по принципу доминирующей целевой установки и подразделяем на информационно-селективные (подача сегментированной информации, формирующей определенный взгляд на проблему и активизирующей ее обсуждение); организационнорегулирующие (создание условий для привлечения фолловеров); психолого-манипулятивные (формирование определенной оценки за счет предъявления селективной информации и эмоциональной аргументации); коммуникативно-поведенческие (стимулирование коммуникативных действий и выработка поведенческих стереотипов в ответ на эмоциональное воздействие) (см.: [Киняшева, 2018; Ребрина, 2021]).

Группы в соцсетях, инициирующие протестную активность, как правило, основываются на объединении вокруг отрицаемого факта, реализуют так называемую «консолидацию против» [Юрина и др., 2017]. При этом в социальных сетях, где количественно преобладают русскоязычные пользователи, отрицаемый факт часто получает саркастическую оценку с целью вызвать общественное порицание [Пильгун, 2018]. В ряде случаев, когда целевая аудитория протестных сообществ представляет собой молодежь, активность стимулируется тезисами и мотивами, содержащими элементы романтизации и героизации протеста. При этом, если главным фокусом является актор протеста, то он также подвержен идеализации на основе преувеличения его положительных качеств. В целом для соцсетей российского сегмента характерны общие для социальных онлайн-платформ признаки: мгновенное вирусное селективное информирование, источником которого являются агенты мобилизации и лидеры мнений данного сообщества, постоянное поддержание обратной связи с представлением статистики посещений, нацеленность на вовлеченность большего числа фолловеров, интерактивность, самоорганизация, децентрализованность, горизонтальность координации действий и мобилизации, трансграничность [Ваньке и др., 2014; Курбатов, Крупенникова, 2016].
Коммуникация внутри соцсетей имеет признаки, характерные для интернет-общения в целом: мультимедийность, креолизованность, интерактивность, равностатусность участников, полидискурсивность, полифоничность.

Эффективность мобилизации в группах соцсетей обеспечивается рядом условий, среди которых можно выделить экстралингвистические и лингвистические.

К экстралингвистическим условиям мы относим использование онлайн-платформы и программного обеспечения, позволяющие участникам соцсетей легко обмениваться информацией с участниками группы, к которой они принадлежат, а также с более широкой интернет-аудиторией; наличие инструментария, дающего возможность добавлять теги, фото-, аудио- и видеоматериалы, быстро размещать и оценивать пользовательский контент; практически стопроцентная обеспеченность участников смартфонами и мобильными приложениями; наличие доступа к высокоскоростному интернету. К экстралингвистическим условиям мы относим социально-психологические и социально-поведенческие факторы, от которых зависит вовлеченность пользователей в протестную деятельность. Среди названных выше социально-психологических факторов мы выделяем неудовлетворенность широких слоев общества состоянием экономики, низким уровнем жизни, неуверенностью в будущем, недоверием к власти, убежденностью в ее коррумпированности и т. д. Обозначенные факторы детерминируют определенные психологические и поведенческие реакции у различных представителей социума, различающихся возрастом, уровнем образования, родом занятий и т. д. Так, высокая протестная активность молодежи до 24 лет обусловлена, на наш взгляд, не только владением интернет-технологиями, но и определенными возрастными психолого-поведенческими характеристиками, а именно: стремлением к активной деятельности, потребностью идентификации себя с социальными группами, тяготением к коллективному, групповому мышлению и формам поведения, интересом к неформальной интеракции. Протестная активность населения среднего возраста детерминирована остро выраженным недоверием к власти, от- 
рицанием положительного результата принятых решений и реализуемых программ социальной сферы (образование, здравоохранение, пенсионное обеспечение, поддержка бизнеса и т. д.), ощущаемым социальным неравенством, неуверенностью в будущем, отсутствием видения четких позитивных перспектив для себя и детей. Среди участников соцсетей среднего возраста доминируют поведенческие стереотипы наблюдателя и умеренного активного пользователя-комментатора.

К лингвистическим условиям можно отнести количественные и качественные текстовые характеристики мобилизационного текста, а именно: среднее количество знаков в посте, наличие / отсутствие восклицательных и вопросительных знаков, скобок, стрелок, эмотиконов [Филиппов, 2020]; количество тематических фрагментов, характер аргументации, стратагемно-тактическая организация текстового фрагмента, способ экспликации адресанта и адресата. В целом мобилизационный потенциал текста, как правило, задается коммуникативным вектором: авторская оценка ситуации $\rightarrow$ побуждение к эмоциональному отклику в рамках предложенной оценки $\rightarrow$ привлечение сторонников из числа потребителей контента $\rightarrow$ «усиление» оценки массовым адресатом - соадресантом [Милованова, Терентьева, 2020].

Изучение протестной коммуникации в соцсетях является актуальным направлением исследований в связи с необходимостью разработки цивилизованных способов разрешения конфликтов между властью и гражданским обществом.

Цель работы состоит в выявлении коллективно-личностных параметров, влияющих на мобилизационный потенциал публикаций в сетевых сообществах.

Сформулированная цель предусматривала следующие исследовательские шаги: описание интерактивного инструментария и изучение статистики сообществ соцсетей, анализ активности членов сообществ (создателей контента, наблюдателей, умеренно активных пользователей); определение адресации, способов экспликации адресанта и адресата в текстах публикаций и ответных интерактивных реакциях участников сообщества, формирования интернет-солидарности; выявление доминантных тактик адресанта и адресата в рамках аргументативной, самопрезентационной, фатической стратегий и релевантных языковых средств.

\section{Материал и методы}

Материалом исследования послужили публикации на русском языке, отвечающие следующим критериям: а) размещены в социальной сети России или на территории России («ВКонтакте», «Одноклассники», «Инстаграм», «Твиттер», «Фейсбук»); б) относятся к контенту сообщества, организованного против чего-либо / кого-либо (например, сообщества в социальной сети «ВКонтакте»: Россия против повышения пенсионного возраста; НЕТ поправкам к Конституции; Против ужесточения законодательства о митингах; сообщества в соцсети «Инстаграм»: Против поправок в Конституцию; Против пенсионной реформы; сообщества в социальной сети «Фейсбук»: Против поголовной вакцинации); в) имеют мобилизационный характер, приурочены к каким-либо событиям, вызвавшим протестные настроения или протестные выступления онлайн / оффлайн; г) размещены в период с 2012 по 2021 год.

Объем выборки составил около 1050 публикаций.

В настоящем исследовании, вслед за многими лингвистами, протест интерпретируется как особая коммуникативная система, характеризующаяся пространственно-временным, предметным и коллективно-личностным измерениями протеста [Бараш, Антоновский, 2018; 2019; Ребрина, Шамне, 2020].

Предметом изучения выступает коллективно-личностное измерение как компонент системно-коммуникативных характеристик русскоязычных практик конфликтной мобилизации в сообществах соцсетей, исследуемый в контексте медиации современной политической коммуникации. Среди параметров коллективно-личностного измерения протестной коммуникации мы выделяем способы дискурсивного конструирования идентичности адресанта и адресата; коммуникативные стратегии и тактики, коммуникативные аспекты солидаризации участников общения. 


\section{МАТЕРИАЛЫ И СООБЩЕНИЯ}

Медиатизация современного общества, проявляющаяся в интеграции цифровых медиа во все социальные процессы, в том числе и политические (подробно об этом см.: [Oniszczuk, 2011]), создает условия для таких трансформаций протестных практик, которые способствуют «реализации технологий “управляемого хаоса" и нацелены на перевод политических систем, институтов, режимов и ситуаций в новое качественное состояние» [Kavanaugh et al., 2017]. Сопряжение в современном социуме протестных практик с процессами медиатизации новейших форматов и механизмов организации коллективных взаимодействий требует их изучения и оценки для дальнейшей разработки алгоритмов управления конфликтными социумами, что определяет актуальность исследования [Гладченко, 2019].

В исследовании были использованы статистические методы. Для установления зависимости между количественными текстовыми характеристиками мобилизационного поста и коэффициентом его вовлеченности Engagement Rate (далее - ER), отражающим выраженное в процентах отношение количества реакций на публикацию к количеству подписчиков, применялся линейный регрессионный анализ на основе стандартного пакета Excel. Для расчета коэффициента вовлеченности поста использовалась формула: $\mathrm{ER}=$ (лайки + комментарии + репосты + клики) / кол-во подписчиков $\times 100 \%$.

\section{Результаты и обсуждение}

\section{Представленность}

социальных сообществ и характеристика активности их участников

Интерфейс страниц социальных сообществ имеет простой, интуитивно понятный стандартный функционал, организуемый вкладками: Информация, Обсуждение, Записи сообщества, Ссылки, Наши мероприятия, Фотоальбомы, Видеозаписи. На странице сообщества отражается статистика активности группы (количество участников, статей, ссылок, данные о динамике публикаций и изменении состава группы; статистика действий: «нравится», «поделились», «просмотров»).

Для оценки эффективности размещенного на странице группы контента учитывались универсальные показатели количественного состава сообществ соцсети (подписчики) и темпа роста аудитории соцсети за определенный промежуток времени (прирост за месяц), рассчитанный в процентах как соотношение новых подписчиков к числу прежних. В приведенной ниже таблице 1 представлена выборка сообществ соцсети ВКонтакте как самой популярной в России, ранжированная по числу подписчиков. Количественные показатели приводятся с учетом данных статистики сообществ.

Статистика сообществ в соцсети ВКонтакте показывает (табл. 1), что прирост аудитории за месяц на $1 \%$ и более демонстриру-

\section{Таблица 1. Динамика состава протестных сообществ в социальной сети «ВКонтакте»}

Table 1. Dynamics of protest communities membership in VKontakte social network

\begin{tabular}{|l|r|c|}
\hline \multicolumn{1}{|c|}{ Название группы } & Подписчики & $\begin{array}{c}\text { Прирост за месяц } \\
\text { (апрель 2021), \% }\end{array}$ \\
\hline Против системы & 554060 & $-14 /-0,00 \%$ \\
\hline МВП & 232153 & $180 / 0,06 \%$ \\
\hline Ешкин Крот & 168268 & $917 / 0,55 \%$ \\
\hline Политкухня преступной власти & 53509 & $1 / 0,01 \%$ \\
\hline Россия без цензуры & 43957 & $28 / 0,07 \%$ \\
\hline Оппозиция & 35569 & $-24 /-0,07 \%$ \\
\hline Россия против повышения пенсионного возраста & 26717 & $-2 / 0,00 \%$ \\
\hline Родина погибает что будем делать & 20531 & $0 / 0,00 \%$ \\
\hline Нитап Rіghts & 20385 & $0 / 0,00 \%$ \\
\hline Народ против повышения пенсий & 16156 & $-56 /-0,35 \%$ \\
\hline Левый фронт & 14599 & $170 / 1,18 \%$ \\
\hline Политические взгляды & 13682 & $2 / 0,01 \%$ \\
\hline Акции протеста & 12910 & $-1 /-0,01 \%$ \\
\hline Марш несогласных (закрытая группа) & 4025 & $0 / 0,00 \%$ \\
\hline
\end{tabular}


М.В. Милованова, Е.В. Терентьева. Конфликтная мобилизация в сообществах социальных сетей России

ют единичные сообщества; в среднем месячный прирост составляет менее $1 \%$ либо имеет отрицательную динамику, что в целом свидетельствует о низкой степени протестных настроений аудитории.

Активность членов сообществ социальных сетей также была проанализирована с помощью коэффициента вовлеченности ER, отражающего отношение количества реакций к количеству подписчиков. Приведенная ниже диаграмма представляет результаты выборочного анализа мобилизационных постов на основе коэффициента вовлеченности ER (рис. 1). Данный показатель рассчитывался для определенного поста (индекс вовлеченности мобилизационного поста). При анализе коэффициента вовлеченности мобилизационного поста применялась общепринятая шкала ER: низкий показатель - ER $<1 \%$; средний - ER от $1 \%$ до $3 \%$; высокий - от 3,5\% до $6 \%$; очень высокий - выше $6 \%$.

Как видно из приведенной диаграммы, только половина постов из нашей выборки демонстрирует высокий и очень высокий индекс вовлеченности. Мы проанализировали посты с высоким и очень высоким индексом вовлеченности по количественным параметрам (количество знаков в посте) с помощью линейного регрессионного анализа с целью установления зависимости количественных показателей текста и коэффициента вовлеченности мобилизационного поста. Результаты построенной регрессии и полученный коэффициент детерминации (R-квадрат) менее 0,5 показывают, что наличие данной зависимости не подтверждается.

\section{Доминантные стратегии \\ и тактики адресанта и адресата в сообществах конфликтной мобилизации в социальных сетях}

Мобилизационный потенциал в социальных сетях обеспечивается определенным набором стратегий и тактик, реализуемых адресантом и адресатом как основными участниками конфликтной коммуникации.

Нами установлены три основные стратегии адресанта: аргументативная, фатическая и самопрезентационная. В качестве языковых средств реализации данных тактик используется лексика с общей положительной (гордость, щуедрый) либо отрицательной (жулик, вор, страшный, бедный) коннотацией, лексика в ироничном употреблении (солниеликий прилетел...; сказочный повысил зарплату себе), общественно-политические, экономические термины (геноцид, война, оккупачия, диктатор, пикет, митинг, коррупция, активы, текущий курс), жаргонизмы

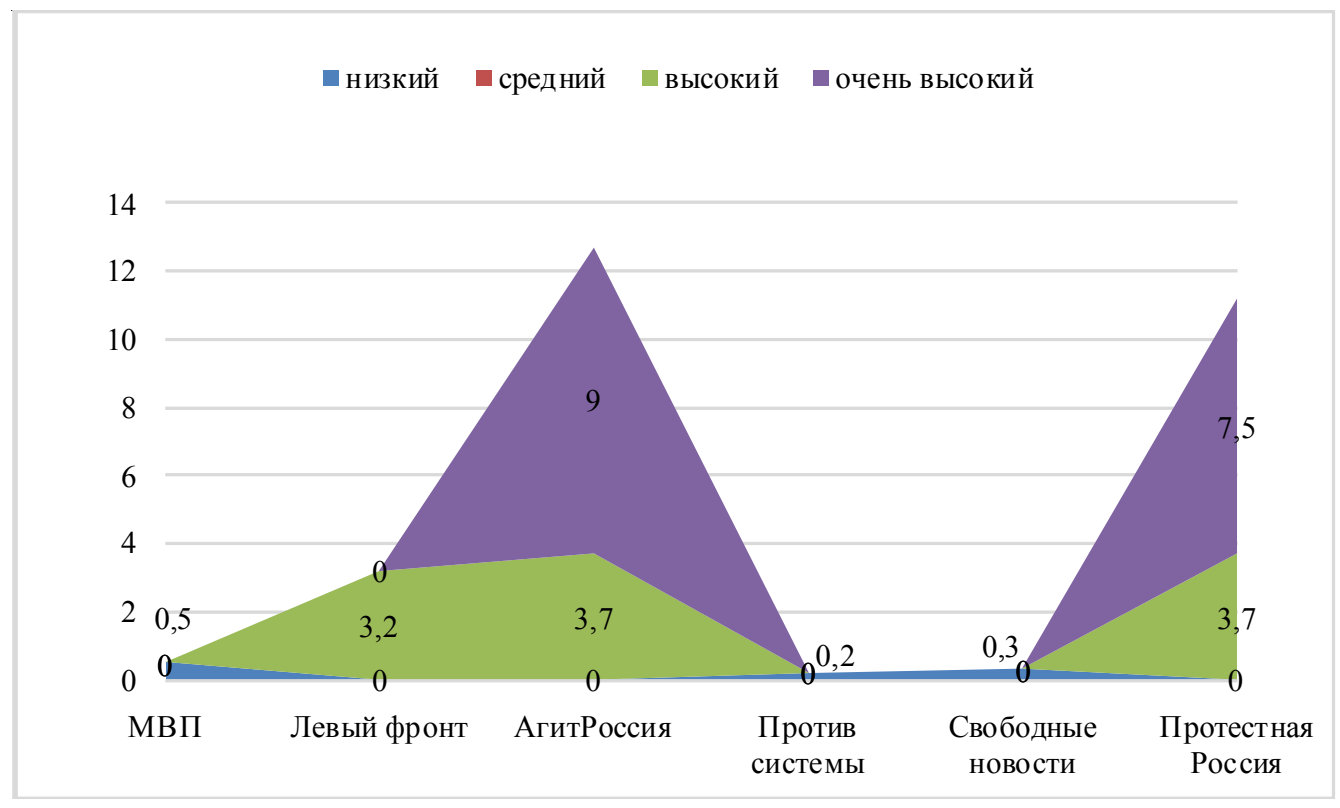

Рис. 1. Коэффициент вовлеченности мобилизационных постов социальной сети «ВКонтакте»

Fig. 1. The coefficient of involvement of mobilization posts of the VKontakte social network 


\section{МАТЕРИАЛЫ И СООБЩЕНИЯ}

(бабло, кореша), бранная лексика (дебильи, идиоты); активно используются числительные, личные местоимения, инфинитивы, формы повелительного наклонения, вопросно-ответные, парцеллированные вводные конструкции, обращения. В целях создания иронии и сарказма адресант прибегает к использованию приемов языковой игры и аллюзии (Они зажрались за Родину - созвучно Они сражались за Родину; С чего загибается Родина - созвучно С чего начинается Родина; Едим Россию - созвучно Единая Россия, СПЕР Банк России - созвучно СБЕР Банк России), обращается к прецедентным текстам интернет-коммуникации (Наташ, они там все уронили / обнулили).

В таблице 2 представлены основные стратегии и тактики адресанта сообщества в соцсетях с количественными данными, типовыми примерами и перечнем релевантных языковых средств, с помощью которых данные тактики получают регулярную реализацию (примеры приводятся с сохранением орфографии и пунктуации источника). Как видно из приведенной таблицы, доминирующей является аргументативная стратегия, которая реализуется, как правило, тактиками фактического и эмоционально-психологического аргументирования.

\section{Таблица 2. Стратегии и тактики адресанта в сообществах конфликтной мобилизации в социальных сетях}

Table 2. Addresser's strategies and tactics in conflict mobilization communities in social networks

\begin{tabular}{|c|c|c|c|}
\hline $\begin{array}{l}\text { Страте- } \\
\text { гия }\end{array}$ & Тактика & Примеры & $\begin{array}{c}\text { Релевантные языковые } \\
\text { средства }\end{array}$ \\
\hline \multirow[t]{3}{*}{$\begin{array}{l}\text { Аргу- } \\
\text { мента- } \\
\text { тивная } \\
(62,2 \%)\end{array}$} & $\begin{array}{l}\text { Фактическое аргу- } \\
\text { ментирование } \\
(49,7 \text { \%) }\end{array}$ & $\begin{array}{l}\text { В то время как каждый третий россиянин живет } \\
\text { на \$ } 8 \text { в день (Росстат), } 500 \text { «сверхбогатых» гра- } \\
\text { ждан РФ владеют активами на сумму } \$ 640 \text { млрд } \\
\text { (более } 46 \text { трлн р), имея в собственности } 40 \% \\
\text { всех финансовых активов страны (подсчитали } \\
\text { аналитики Bоston Cопsulting Group). То есть со- } \\
\text { стояние 0,0001 \% взрослого населения России } \\
\text { превысило мељжународные резервы страны (ЕК) }\end{array}$ & $\begin{array}{l}\text { Общественно-полити- } \\
\text { ческие и экономические } \\
\text { термины, имена собст- } \\
\text { венные, количественные } \\
\text { числительные, формы } \\
\text { глагола в изъявительном } \\
\text { наклонении, парцелли- } \\
\text { рованные, вставные } \\
\text { конструкции }\end{array}$ \\
\hline & $\begin{array}{l}\text { Эмоционально-пси- } \\
\text { хологическое аргу- } \\
\text { ментирование с } \\
\text { элементами идеали- } \\
\text { зации и героизации } \\
\text { актора протеста } \\
(47 \%)\end{array}$ & 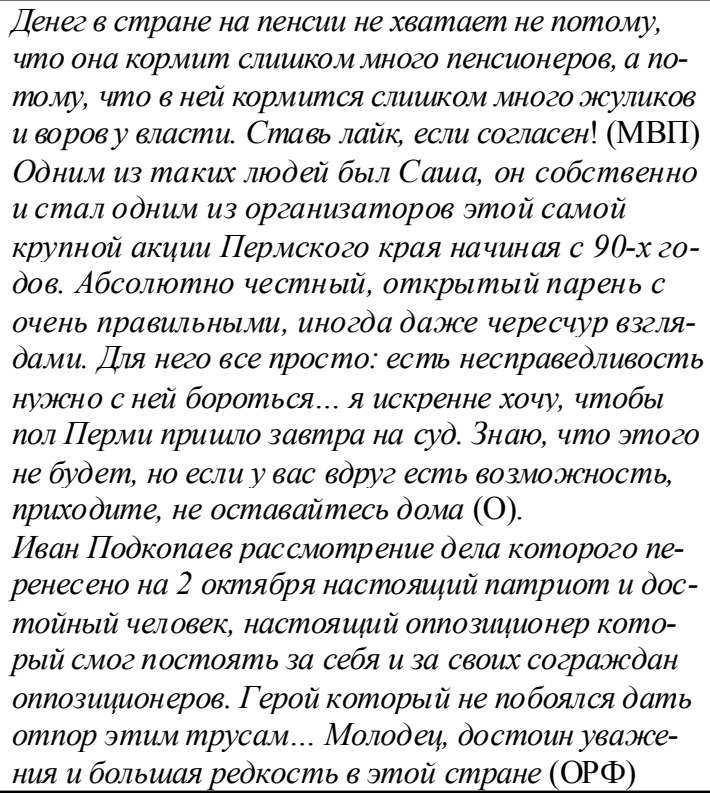 & $\begin{array}{l}\text { Лексические единицы с } \\
\text { положительной либо } \\
\text { отрицательной семанти- } \\
\text { кой, имена собственные; } \\
\text { местоимения, формы } \\
\text { глагола в изъявительном } \\
\text { наклонении, императи- } \\
\text { вы; побудительные, ус- } \\
\text { ловные, парцеллирован- } \\
\text { ные конструкции }\end{array}$ \\
\hline & $\begin{array}{l}\text { Логическое аргу- } \\
\text { ментирование } \\
(3,3 \%)\end{array}$ & $\begin{array}{l}\text { Вчера они отобрали у нас право на пенсию, сегодня } \\
\text { принудительная вакцинация, а завтра чего ожс- } \\
\text { дать? Обязательно приходите на выборы и вос- } \\
\text { пользуйтесь своим правом голоса, потому, что ес- } \\
\text { ли они останутся, то завтра отберут и его! (ЛФ) }\end{array}$ & $\begin{array}{l}\text { Лексические единицы, } \\
\text { эксплицирующие поря- } \\
\text { док мысли, причинно- } \\
\text { следственные, вопросно- } \\
\text { ответные конструкции }\end{array}$ \\
\hline
\end{tabular}


Продолжение таблищь 2

Continuation of Table 2

\begin{tabular}{|c|c|c|c|}
\hline $\begin{array}{l}\text { Страте- } \\
\text { гия }\end{array}$ & Тактика & Примеры & $\begin{array}{c}\text { Релевантные языковые } \\
\text { средства }\end{array}$ \\
\hline \multirow[t]{3}{*}{$\begin{array}{l}\text { Фатиче- } \\
\text { ская } \\
(25,4 \%)\end{array}$} & $\begin{array}{l}\text { Консолидирующий } \\
\text { призыв к адресату } \\
(78,8 \text { \%) }\end{array}$ & $\begin{array}{l}\text { Мыл предлагаем собраться вместе - и организо- } \\
\text { вать Объединенный Московский фронт. Наша } \\
\text { иель - добиться коренного пересмотра политики } \\
\text { столичных властей. } \\
\text { Нужно объединиться и заставить уйти все ру- } \\
\text { ководство мэрии... Это дело не одного дня, но } \\
\text { отступать нам уже некуда. Позади - Москва! } \\
\text { Для спасения города нужнны ваш опыт, ум, прин- } \\
\text { иипиальность, настойчивость! Создадим Объе- } \\
\text { диненный Московский фронт вместе! (SN) } \\
\text { ПРОСНИТЕСь ЛЮДИ ПОКА НЕ ПОЗДНО!!! } \\
\text {.. пригласите всех своих друзей в группу если } \\
\text { вам не безразлична своя судьба и судьба своей } \\
\text { Родины! (РП) }\end{array}$ & $\begin{array}{l}\text { Лексические единицы с } \\
\text { положительной семан- } \\
\text { тикой, лексические еди- } \\
\text { ницы со значением дол- } \\
\text { женствования, необхо- } \\
\text { димости, совместного } \\
\text { действия; личные ме- } \\
\text { стоимения, императивы; } \\
\text { восклицательные конст- } \\
\text { рукции, обращения }\end{array}$ \\
\hline & $\begin{array}{l}\text { Солидаризирующая } \\
\text { похвала массовому } \\
\text { адресату }(9,7 \text { \%) }\end{array}$ & $\begin{array}{l}\text { Это Хабаровск, где протесты не утихают уже } \\
78(!) \text { дней. Восхищает стойкость этих прекрас- } \\
\text { ных людей, хабаровчане гордость и совесть Рос- } \\
\text { сии (РБЦ) } \\
\text { Спасибо молодым ребятам, которые все эти ме- } \\
\text { сяцы не переставали поддерживать Сашу, поч- } \\
\text { ти каждый день организовывали одиночные пи- } \\
\text { кетьл. У нас очень крутая молодежь в Перми, ей } \\
\text { можно гордиться (О) }\end{array}$ & $\begin{array}{l}\text { Лексические единицы с } \\
\text { положительной семан- } \\
\text { тикой, имена собствен- } \\
\text { ные; восклицательные } \\
\text { конструкции }\end{array}$ \\
\hline & $\begin{array}{l}\text { Экспликация во- } \\
\text { влечения в актив- } \\
\text { ные онлайн- и оф- } \\
\text { флайн-действия } \\
(11,5 \text { \%) }\end{array}$ & $\begin{array}{l}\text { Сделайте максимальное количество репостов } \\
\text { этого поста, максимальное количество коммен- } \\
\text { тариев, и отметок аккаунта!!! (ПП) } \\
\text { Ваш репост ускорит отрезвление страны (ЕК) } \\
\text { Оставляем в комментариях точное время, город } \\
\text { и адрес, где будут проходить акции протеста, а } \\
\text { мы будем публиковать информацию в нашем со- } \\
\text { обществе (РППВ) } \\
\text { Все на митинг! Завтра, в субботу, } 17 \text { августа } \\
2019 \text { г. на проспекте Академика Сахарова в 12:00 } \\
\text { (ЛФ) } \\
\text { Митинг в Москве. Пушкинская площадь. Против } \\
\text { лже-вакиинации от коронавируса. Выходим все! } \\
\text { Максимальный репост. Свобода слова или кляп с } \\
\text { намордниками (ЯВП) } \\
\text { Пожалуйста, не проходите мимо! Давайте это } \\
\text { максимально распространим в сети! Только так } \\
\text { нас усльшиат! Максимальньй репост!!! (МВП) }\end{array}$ & $\begin{array}{l}\text { Лексические единицы, } \\
\text { номинирующие комму- } \\
\text { никативное поведение в } \\
\text { социальных сетях, лек- } \\
\text { сические единицы с по- } \\
\text { ложительной семанти- } \\
\text { кой имена собственные, } \\
\text { местоимения, императи- } \\
\text { вы, формы глаголов на- } \\
\text { стоящего времени с се- } \\
\text { мантикой побуждения к } \\
\text { действию; побудитель- } \\
\text { ные, восклицательные } \\
\text { конструкции }\end{array}$ \\
\hline $\begin{array}{l}\text { Само- } \\
\text { презен- } \\
\text { тацион- } \\
\text { ная } \\
(12,4 \%)\end{array}$ & $\begin{array}{l}\text { Идентификации с } \\
\text { массовым адреса- } \\
\text { том }(42,2 \%),\end{array}$ & $\begin{array}{l}\text { Власть плюёт на нас, решает кого допустить } \\
\text { до выборов, а кого нет, в каком дворе построить } \\
\text { небоскреб, где срубить сквер, придумывает но- } \\
\text { вые налоги, поборы, хочет чтобы мы платили за } \\
\text { всё - медицину, образование, даже дороги плат- } \\
\text { ные для нас с вами во всю строят! Скажем им: } \\
\text { «хватит!» До встречи на митинге Ө (ЛФ) }\end{array}$ & $\begin{array}{l}\text { Лексические единицы с } \\
\text { семантикой единения, } \\
\text { инклюзивные формы ме- } \\
\text { стоимения, формы глаго- } \\
\text { лов будущего времени с } \\
\text { семантикой побуждения } \\
\text { к действию, конструкции } \\
\text { с прямой речью } \\
\end{array}$ \\
\hline
\end{tabular}




\section{МАТЕРИАЛЫ И СООБЩЕНИЯ}

Окончание таблицьь 2

End of Table 2

\begin{tabular}{|c|c|c|c|}
\hline $\begin{array}{l}\text { Страте- } \\
\text { гия }\end{array}$ & Тактика & Примеры & $\begin{array}{c}\text { Релевантные языковые } \\
\text { средства }\end{array}$ \\
\hline \multirow[t]{3}{*}{$\begin{array}{l}\text { Само- } \\
\text { презен- } \\
\text { тацион- } \\
\text { ная } \\
(12,4 \text { \%) }\end{array}$} & $\begin{array}{l}\text { Прот ивопоставле- } \\
\text { ние неодобряемому } \\
\text { оппоненту }(41,3 \%)\end{array}$ & $\begin{array}{l}\text { Друзья, знаете ли вы, что итальянская компания } \\
\text { «Епеl» владеет Невинномысской ГРЭС в Став- } \\
\text { ропольском крае, Конаковской ГРЭС в Тверской } \\
\text { обл. ... Все это было продано Чубайсом и Ко в } \\
\text { рамках реформь РАО ЕЭС. Такие дела. Они за- } \\
\text { жрались за Родину! } \\
\text { Ставь, О если согласен! (МВП) } \\
\text { Разворовали все! } \\
\text { Всех пенсионеров Думы отправить на минималь- } \\
\text { ную пенсию 9800 Кто за? (МВП) }\end{array}$ & $\begin{array}{l}\text { Лексические единицы с } \\
\text { негативной семантикой, } \\
\text { разговорная лексика, } \\
\text { имена собственные; ме- } \\
\text { стоимения, формы гла- } \\
\text { гола в изъявительном } \\
\text { наклонении; восклица- } \\
\text { тельные, вопроситель- } \\
\text { ные конструкции, обра- } \\
\text { щения }\end{array}$ \\
\hline & $\begin{array}{l}\text { Самопредставление } \\
(10 \%)\end{array}$ & 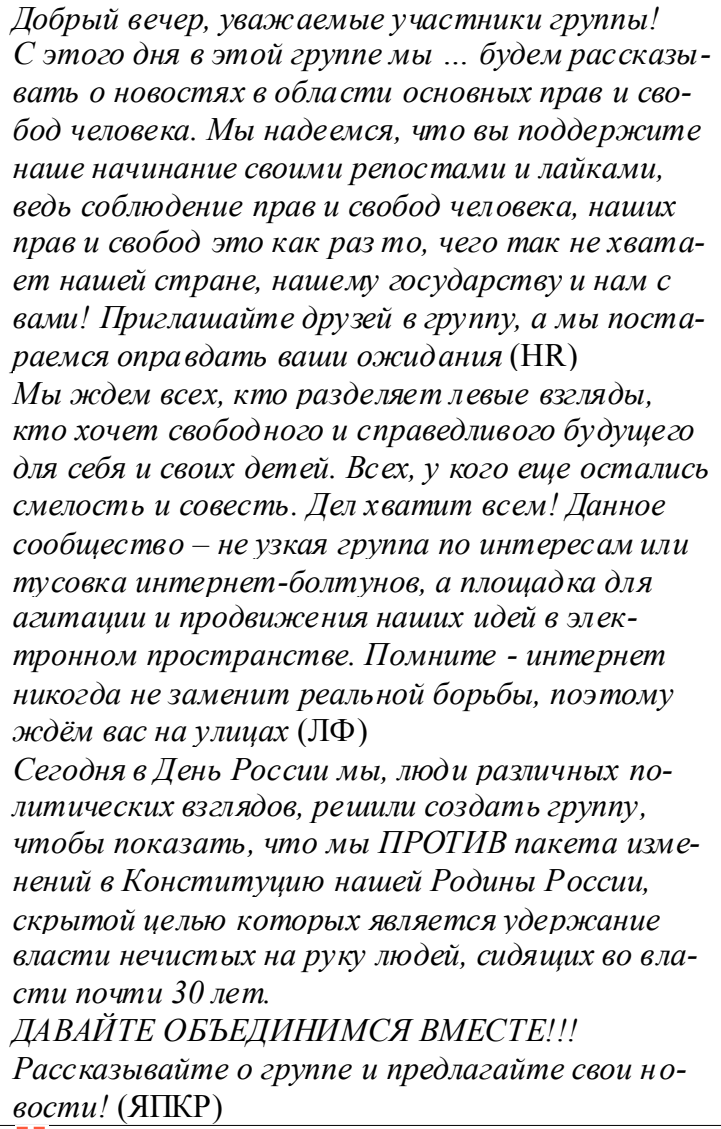 & $\begin{array}{l}\text { Лексические единицы с } \\
\text { положительной семан- } \\
\text { тикой, семантикой еди- } \\
\text { нения, имена собствен- } \\
\text { ные, лексические еди- } \\
\text { ницы, номинирующие } \\
\text { коммуникативное пове- } \\
\text { дение в социальных се- } \\
\text { тях; местоимения, им- } \\
\text { перативы, восклица- } \\
\text { тельные конструкции, } \\
\text { обращения }\end{array}$ \\
\hline & $\begin{array}{l}\text { Предъявление кол- } \\
\text { лективной позиции } \\
\text { группы }(6,5 \text { \%) }\end{array}$ & $\begin{array}{l}\text { !! "Нет прививочному террору!" } \\
20 \text { июня, 12:00 (мск) состоится интернет-ми- } \\
\text { тинг «Нет прививочному террору!» в связи с но- } \\
\text { выми ограничениями в Москве и других регионах } \\
\text { России. Мы считаем, что система власти будет } \\
\text { вводить очередные локдаунь по всей стране, } \\
\text { чтобы использовать это для стимуляции пого- } \\
\text { ловной вакцинации (РП) }\end{array}$ & $\begin{array}{l}\text { Лексические единицы с } \\
\text { оценочной семантикой, } \\
\text { имена собственные, } \\
\text { инклюзивные место- } \\
\text { имения, восклицатель- } \\
\text { ные конструкции, сти- } \\
\text { листически маркиро- } \\
\text { ванные конструкции- } \\
\text { лозунги со значением } \\
\text { «протестовать против } \\
\text { чего-либо» }\end{array}$ \\
\hline
\end{tabular}


М.В. Милованова, Е.В. Терентьева. Конфликтная мобилизация в сообществах социальных сетей России

На уровне текста тактика фактического аргументирования представлена несколькими вариантами структурной организации мобилизационных убеждающих фрагментов. Основным компонентом их структуры является соположение специально подобранных фактических аргументов, сопоставление которых должно вызвать у адресата негативную эмоциональную реакцию и прогнозируемый протестный отклик. Данная структура реализуется тремя вариантами (рис. 2).

Вариант 1 представляет собой простую структуру, включающую селективную, тщательно отобранную адресатом фактическую информацию, как правило, манипулятивного характера (в примерах отмечена полужирным шрифтом), ее совмещение и прогнозируемый вывод адресата:

Россия попала в топ-5 стран, чье население беднеет быстрее всего. По данным Global Wealth Report, за год средний россиянин стал беднее почти на \$700, а благосостояние россиян снизилось на 9,9\%. Параллельно этому Россия заняла 1-е место в мире по доле состояния миллиардеров от ВВП страны, которая за год выросла на 10 процентных пунктов - до $35 \%$ (The Financial Times).

Россия оказалась в топ-5 экономик мира по падению благосостояния населения.

Россия заняла 1 место в мире по доле состояния миллиардеров от ВВП страны (35\%) (ЕК);
Депутат Областной думы, стаж 8 лет, пенсия 100.000 руб.

Ветеран ВОВ, стаж 60 лет, пенсия 16.000 руб;

В свое время дорогая нефть позволила Норвегии поднять пенсию до 20554 крон в месяи (176400 рублей).

России дорогая нефть позволила увеличить число миллиардеров до 99. Все! (МВП).

Вариант 2 осложнен включением в структуру поста комментария, содержащего похвалу, ироническое замечание, например:

...Пособие для малообеспеченных родителейодиночек: на ребенка от 8 до 17 лет в среднем будут выплачивать по 5,5 тыс. р в месяи. На такие выплаты до конца года выделено 36 млрд р. Щедро. Если не учитыввать, что это в 3 раза меньше, чем Путин вылделил из российского бюджета на поддержку белорусского диктатора Лукашенко (\$1,5 млрд или более 108 млрд р по текущему курсу)

На пособия бедным родителям-одиночкам в России вылделили 36 млрд руб.

На поддержку одного белорусского батькиодиночки из бюджета РФ выделили 108.млрдр (ЕК).

Вариант 3 включает эмоциональный комментарий, который является фоном для селективно-манипулятивной аргументации:

Ровно 80 лет назад в нашей стране началась страшная война. Судя по происходящему

Вариант 1

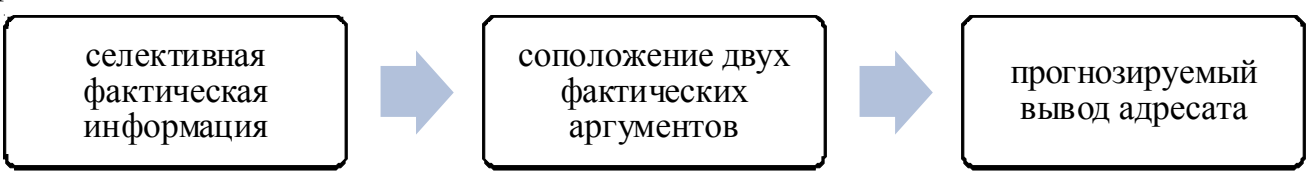

Вариант 2

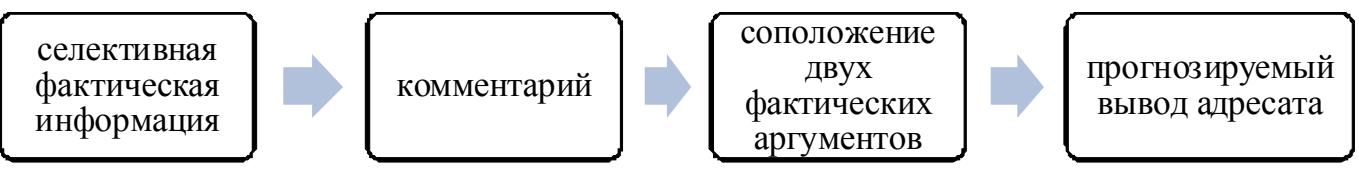

Вариант 3

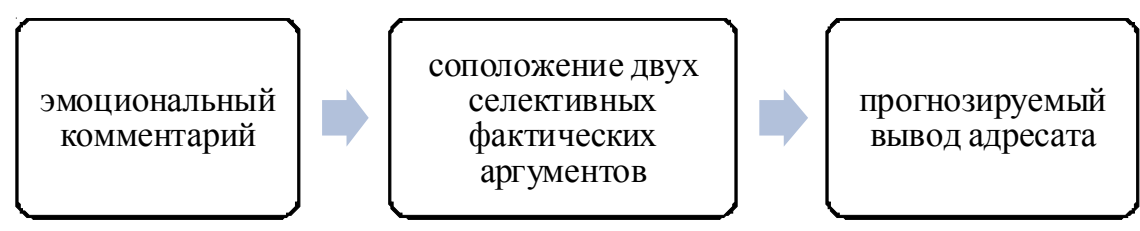

Рис. 2. Структура организации мобилизационных убеждающих фрагментов

Fig. 2. The structure of the organization of mobilization persuasive fragments 


\section{МАТЕРИАЛЫ И СООБЩЕНИЯ}

сейчас в России, оккупачия и война с народом продолжается и по сей день (но уже без нападения извне).

94-летняя ветеран ВОВ... мечтает о ванной и туалете в доме. Чтобы исполнить ее мечту в Интернете всем миром собирают 200 тысяч рублей.

Росгвардия закупит дубинки-электрошокеры на $\mathbf{3 0}$ млн. рублей для разгона митингов. Этих денег хватило бы на решение бытовых проблем 150 ветеранов (ЕК).

Мобилизационный текст на основе эмоционально-психологического и логического аргументирования строится по однотипной модели:

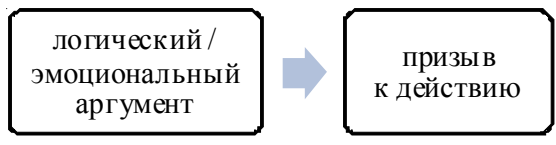

Вчера они отобрали у нас право на пенсию, сегодня принудительная вакцинация, а завтра чего ожидать? Обязательно приходите на выборы и воспользуйтесь своим правом голоса, потому, что если они останутся, то завтра отберут и его!; Нищче ветерань ждут от на действий, приходи на выборы (ЛФ).
Таким образом, доминирующей является стратегия аргументирования, реализуемая адресантом преимущественно посредством специально отобранных фактов и апелляции к этическим и эмоциональным доводам. Установление и поддержание адресантом контакта обеспечивается чаще всего с помощью консолидирующих призывов к членам сообщества; самопрезентация актуализируется преимущественно за счет идентификации с адресатом и противопоставления неодобряемому оппоненту.

В таблице 3 представлены выявленные стратегии и тактики адресата в исследуемых сообществах. Отличие от стратегий и тактик, реализуемых адресантом, состоит в использовании более разнообразного набора тактик внутри самопрезентационной стратегии, в более активном использовании эмотиконов и в более конфликтогенном характере коммуникации, что достигается за счет употребления сниженной, грубой, бранной лексики, эвфемизмов нецензурных слов и выражений, окказионализмов, созданных на основе созвучия с непристойными словами, обсценной лексики.

\section{Таблица 3. Стратегии и тактики адресата в сообществах конфликтной мобилизации}

в социальных сетях

Table 3. Addressee's strategies and tactics in conflict mobilization communities in social networks

\begin{tabular}{|c|c|c|c|}
\hline $\begin{array}{l}\text { Страте- } \\
\text { гия }\end{array}$ & Тактика & Примеры & $\begin{array}{c}\text { Релевантные языковые } \\
\text { средства }\end{array}$ \\
\hline $\begin{array}{l}\text { Аргу- } \\
\text { мента- } \\
\text { тивная } \\
(30,4 \%)\end{array}$ & $\begin{array}{l}\text { Фактическое аргу- } \\
\text { ментирование } \\
(11,6 \%)\end{array}$ & 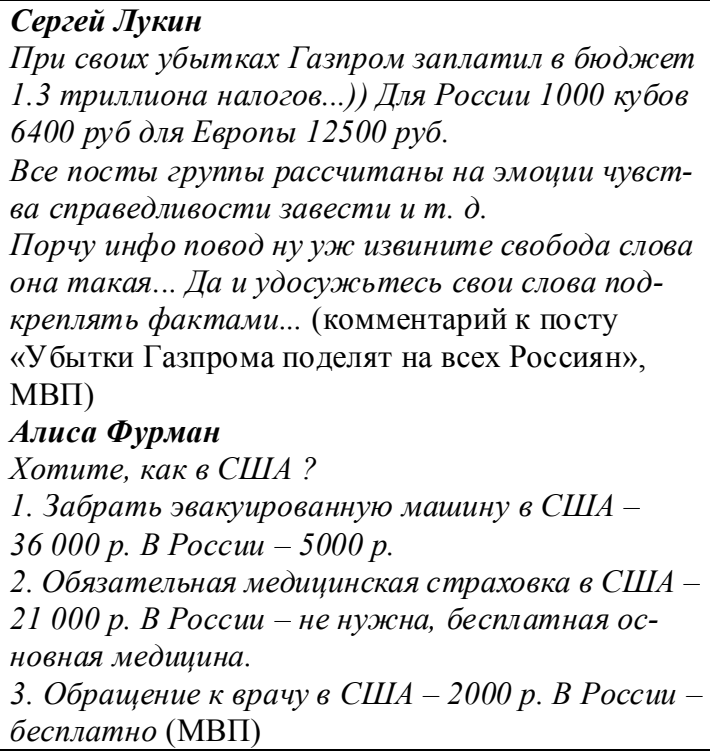 & $\begin{array}{l}\text { Общественно-политичес- } \\
\text { кие и экономические } \\
\text { термины, имена собст- } \\
\text { венные, количественные } \\
\text { числительные }\end{array}$ \\
\hline
\end{tabular}


Продолжение таблищы 3

Continuation of Table 3

\begin{tabular}{|c|c|c|c|}
\hline $\begin{array}{l}\text { Страте- } \\
\text { гия }\end{array}$ & Тактика & Примеры & $\begin{array}{c}\text { Релевантные языковые } \\
\text { средства }\end{array}$ \\
\hline $\begin{array}{l}\text { Аргу- } \\
\text { мента- } \\
\text { тивная } \\
(30,4 \%)\end{array}$ & $\begin{array}{l}\text { Эмоционально-пси- } \\
\text { хологическое аргу- } \\
\text { ментирование } \\
(85 \%)\end{array}$ & 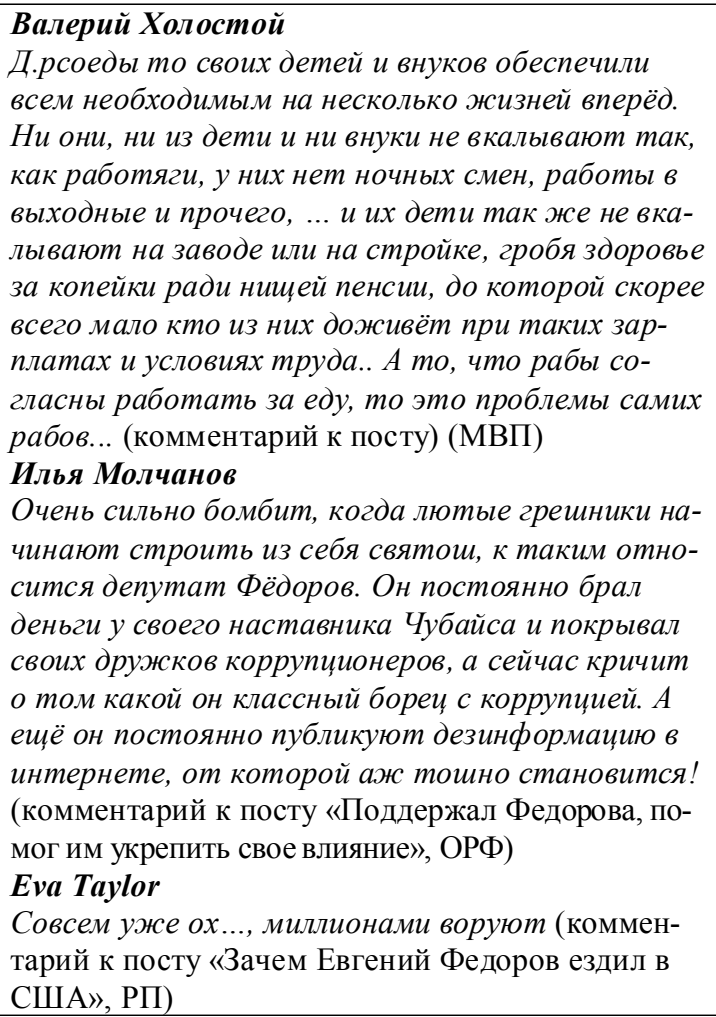 & $\begin{array}{l}\text { Разговорная лексика и } \\
\text { фразеология, жаргониз- } \\
\text { мы, бранные слова, ан- } \\
\text { тонимы, имена собст- } \\
\text { венные; местоимения, } \\
\text { формы глагола в изъяви- } \\
\text { тельном наклонении, } \\
\text { присоединительные кон- } \\
\text { струкции, ряды одно- } \\
\text { родных членов }\end{array}$ \\
\hline & $\begin{array}{l}\text { Логическое аргу- } \\
\text { ментирование } \\
(3,4 \%)\end{array}$ & $\begin{array}{l}\text { Александр Демидов } \\
\text { Опять идиоты сравнивают круглое с деревяннылм } \\
\text { (комментарий к посту «Госкапитализм вместо } \\
\text { олигархов», МВП); } \\
\text { Нина Хромова (Степанидина) ответила Руслану } \\
\text { Кто с головой дружит, тот никогда, никакой } \\
\text { вакцины делать не будет, ни себе, ни детям, ни } \\
\text { внукам. ...Если бы они так заботились о народе, } \\
\text { не было бы ... поддельных лекарств, геночидных } \\
\text { прививок, прибавки } 5 \text { лет к пенс возрасту копееч- } \\
\text { ных пенсий и зарплат мизерных и т.д. Думайте } \\
\text { люди головой, для чего у вас мозги? Включите ло- } \\
\text { гическое мышление (ЛФ) } \\
\text { Если бы все вместе забастовали, тогда и зар- } \\
\text { платы поднялись бы..., а пока работают и так, } \\
\text { то зачем платит больше))) (комментарий к по- } \\
\text { сту) (МВП) }\end{array}$ & $\begin{array}{l}\text { Лексические единицы, } \\
\text { эксплицирующие нару- } \\
\text { шения логики, импера- } \\
\text { тивы; вопросительные, } \\
\text { причинно-следственные, } \\
\text { условные конструкции }\end{array}$ \\
\hline
\end{tabular}




\section{МАТЕРИАЛЫ И СООБЩЕНИЯ}

\section{Продолжение таблицы 3}

Continuation of Table 3

\begin{tabular}{|c|c|c|c|}
\hline $\begin{array}{c}\text { Страте- } \\
\text { гия }\end{array}$ & Тактика & Примеры & $\begin{array}{c}\text { Релевантные языковые } \\
\text { средства }\end{array}$ \\
\hline \multirow[t]{3}{*}{$\begin{array}{l}\text { Фатиче- } \\
\text { ская } \\
(19,9 \%)\end{array}$} & $\begin{array}{l}\text { Консолидирующий } \\
\text { призыв / обраще- } \\
\text { ние к членам сооб- } \\
\text { щества }(87,4 \text { \%) }\end{array}$ & 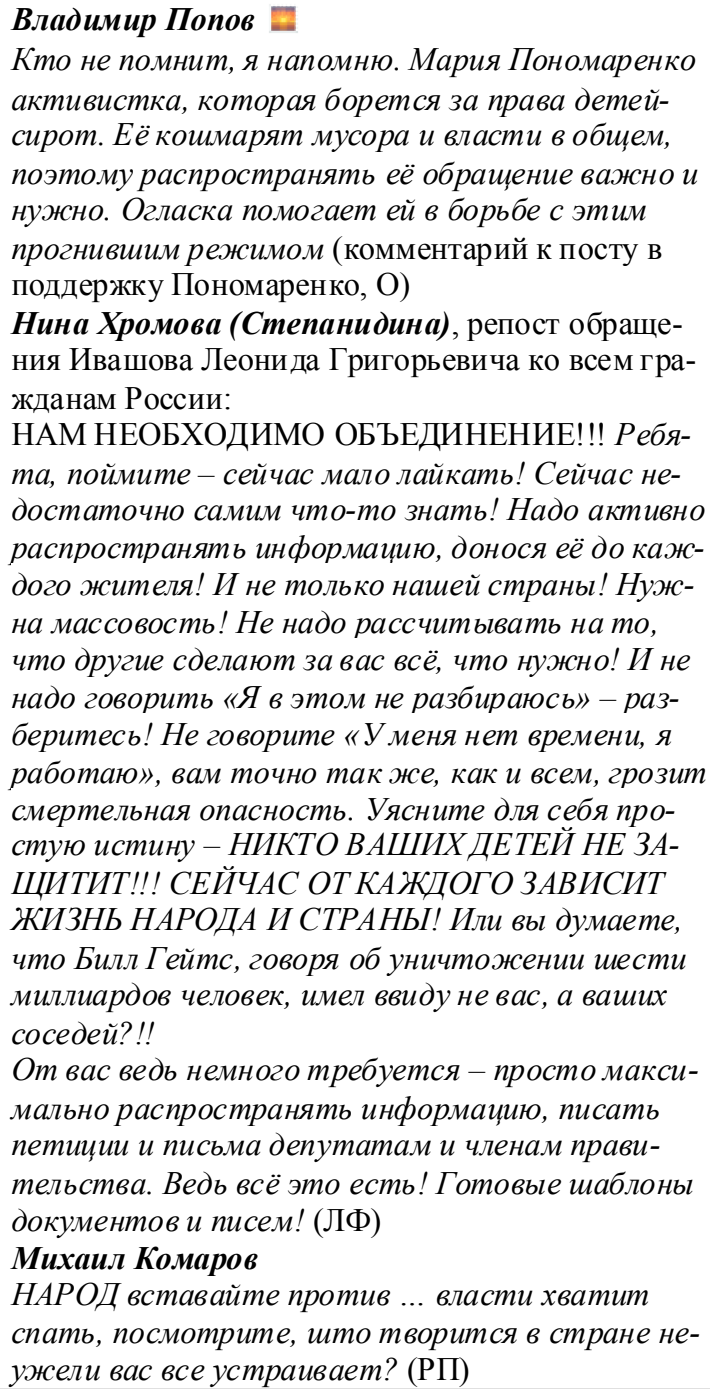 & $\begin{array}{l}\text { Лексические единицы со } \\
\text { значением долженство- } \\
\text { вания, необходимости, } \\
\text { совместного действия, } \\
\text { имена собственные, жар- } \\
\text { гонизмы, инклюзивные } \\
\text { местоимения, императи- } \\
\text { вы, восклицательные } \\
\text { конструкции, обращения }\end{array}$ \\
\hline & $\begin{array}{l}\text { Солидаризирующая } \\
\text { похвала члену(-ам) } \\
\text { сообщества }(9,7 \%)\end{array}$ & 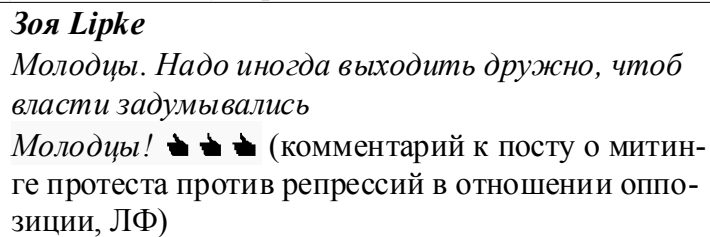 & $\begin{array}{l}\text { Лексические единицы с } \\
\text { положительной семанти- } \\
\text { кой; восклицательные } \\
\text { конструкции }\end{array}$ \\
\hline & $\begin{array}{l}\text { Экспликация во- } \\
\text { влечения в обсуж- } \\
\text { дение }(2,9 \%)\end{array}$ & $\begin{array}{l}\text { Vladislav Tarlakovsky } \\
\text { Друзья, прошу Вашего репоста! } \\
\text { Хочу посмотреть просыпается ли русский на- } \\
\text { род.. } \\
\text { Так вот, голосовали ли Вы о поправках в консти- } \\
\text { туциию? (ЯПКР) }\end{array}$ & $\begin{array}{l}\text { Лексические единицы, } \\
\text { номинирующие комму- } \\
\text { никативное поведение в } \\
\text { сообществах соцсетей, } \\
\text { лексические единицы с } \\
\text { положительной семанти- } \\
\text { кой, перформативные } \\
\text { глаголы; побудительные, } \\
\text { восклицательные, вопро- } \\
\text { сительные конструкции }\end{array}$ \\
\hline
\end{tabular}


Продолжение таблищы 3

Continuation of Table 3

\begin{tabular}{|c|c|c|c|}
\hline $\begin{array}{l}\text { Страте- } \\
\text { гия } \\
\end{array}$ & Тактика & Примеры & $\begin{array}{c}\text { Релевантные языковые } \\
\text { средства } \\
\end{array}$ \\
\hline \multirow[t]{5}{*}{$\begin{array}{l}\text { Само- } \\
\text { презен- } \\
\text { тацион- } \\
\text { ная } \\
(49,7 \%)\end{array}$} & $\begin{array}{l}\text { Тактика солидари- } \\
\text { зирующей иденти- } \\
\text { фикации с участни- } \\
\text { ком(-ами) сообще- } \\
\text { ства }(18,7 \text { \%) }\end{array}$ & 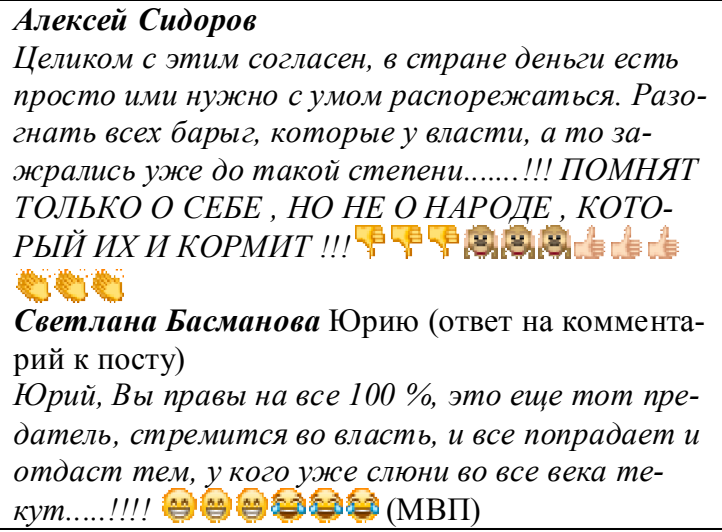 & $\begin{array}{l}\text { Лексические единицы с } \\
\text { семантикой поддержки, } \\
\text { разговорные лексические } \\
\text { единицы; личные место- } \\
\text { имения, конструкции со } \\
\text { значением долженство- } \\
\text { вания, восклицательные } \\
\text { конструкции }\end{array}$ \\
\hline & $\begin{array}{l}\text { Тактика отрица- } \\
\text { тельной идентифи- } \\
\text { кации с участника- } \\
\text { ми сообщества } \\
(26,1 \%)\end{array}$ & 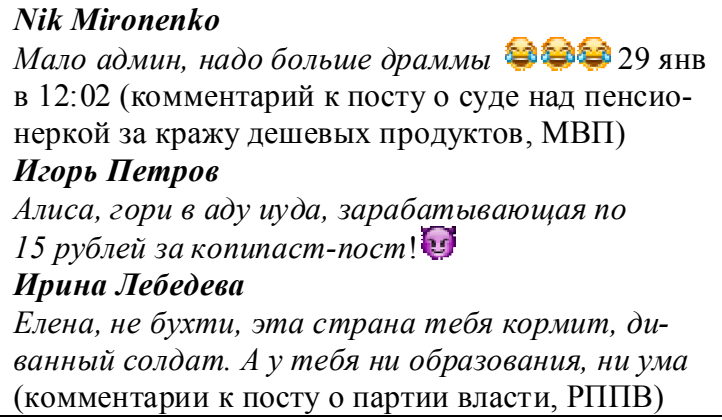 & $\begin{array}{l}\text { Лексические единицы с } \\
\text { негативной семантикой, } \\
\text { разговорная, бранная } \\
\text { лексика, имена собст- } \\
\text { венные; местоимения, } \\
\text { императивы; восклица- } \\
\text { тельные конструкции, } \\
\text { обращения }\end{array}$ \\
\hline & $\begin{array}{l}\text { Тактика солидари- } \\
\text { зирующей иденти- } \\
\text { фикации с адресан- } \\
\text { том }(22,1 \%)\end{array}$ & $\begin{array}{l}\text { Татьяна Жунева } \\
\text { Мы Российский, бедный, нищий народ, в каком } \\
\text { строю живём???? Демократизм??? Плутокра- } \\
\text { тизм??? Идиотизм??? Вроде нас, людей, охра- } \\
\text { няют от кого-то, а на самом деле в каждом из } \\
\text { нас видят врага, шпиона? Комментарий к нега- } \\
\text { тивному посту о власти (РП) }\end{array}$ & $\begin{array}{l}\text { Общественно-политичес- } \\
\text { кая лексика, синонимы; } \\
\text { инклюзивные местоиме- } \\
\text { ния, парцеллированные } \\
\text { вопросительные конст- } \\
\text { рукции }\end{array}$ \\
\hline & $\begin{array}{l}\text { Тактика отрица- } \\
\text { тельной идентифи- } \\
\text { кации с адресантом } \\
(11,6 \%)\end{array}$ & $\begin{array}{l}\text { Александр Чурилов } \\
\text { Просто девочка пока не столкнулась, не едросы } \\
\text { не путин не помогут, если подхватит эту заразу, } \\
\text { а врачи у нас уже поколение 90, сессии сдавали за } \\
\text { бабки, а теперь окей гугл (комментарий к посту о } \\
\text { поддержке пикета против масочного режима, } \\
\text { РППВ) }\end{array}$ & $\begin{array}{l}\text { Разговорная лексика, } \\
\text { жаргонизмы, лексиче- } \\
\text { ские единицы с негатив- } \\
\text { ной семантикой }\end{array}$ \\
\hline & $\begin{array}{l}\text { Противопоставле- } \\
\text { ние общему оппо- } \\
\text { ненту }(21,5 \text { \%) }\end{array}$ & $\begin{array}{l}\text { Глеб Рыбаков } \\
\text { Федоров это истинное лицо современной власти, } \\
\text { ну или большей ее части. Выйди скажи что закон } \\
\text { плохой, а потом в тихую проголосуй, все же глу- } \\
\text { пые, никто проверять не будет. Говори что в } 90 \\
\text { все разворовали, а сам Чубайса покрывай и под- } \\
\text { держивай, он же тебе помог. И денег из бюдже- } \\
\text { та не забывай освоить. Бесят такие двуличные } \\
\text { «атриоты»! (комментарий к посту «Зачем Ев- } \\
\text { гений Федоров ездил в США», РППВ) }\end{array}$ & $\begin{array}{l}\text { Лексические единицы с } \\
\text { негативной семантикой, } \\
\text { разговорная лексика, } \\
\text { имена собственные; ме- } \\
\text { стоимения, глаголы по- } \\
\text { велительного наклоне- } \\
\text { ния в значении изъяви- } \\
\text { тельного для передачи } \\
\text { нежелательности дейст- } \\
\text { вий; восклицательные } \\
\text { конструкции, обращения }\end{array}$ \\
\hline
\end{tabular}




\section{МАТЕРИАЛЫ И СООБЩЕНИЯ}

Окончание таблищь 3

End of Table 3

\begin{tabular}{|c|c|c|c|}
\hline $\begin{array}{l}\text { Страте- } \\
\text { гия }\end{array}$ & Тактика & Примеры & $\begin{array}{c}\text { Релевантные языковые } \\
\text { средства }\end{array}$ \\
\hline $\begin{array}{l}\text { Само- } \\
\text { презен- } \\
\text { тацион- } \\
\text { ная } \\
(49,7 \text { \%) }\end{array}$ & $\begin{array}{l}\text { Предъявление } \\
\text { субъективной по- } \\
\text { зиции }(28,2 \%)\end{array}$ & $\begin{array}{l}\text { Владимир Агафонов ответил Нине } \\
\text { Да, хочу ещё сказать - .. ну я им в обсуждениях } \\
\text { ответил - «НЕТ ДОВЕРИЯ ВЛАСТЯМ, А ВАК- } \\
\text { ЦИНА СЫРАЯ, НЕ ПРОШЛА ЕЩЁ СВОЁ ВРЕ- } \\
\text { МЯ НА ИСПЫТАНИЯХ У ЖИВОТНЫХ» (ком- } \\
\text { ментарий к посту о вакцинации, ЛФ) } \\
\text { Елена Батуева } \\
\text { Как бы четвёртой волной не стал русский } \\
\text { штамм, «народный протест». А этот вирус у } \\
\text { власти бедный будет (комментарий к посту о } \\
\text { вакцинации, ПС). } \\
\text { Алексей Лебедев } \\
\text { Знаете, что я думаю? Каждый чиновник ворует } \\
\text { и за это я их презираю. Если чиновник ворует } \\
\text { нужна смертная казнь публичная ему скажем } \\
\text { или кому-то из членов семьи ...тюрьмь они не } \\
\text { боятся все равно выпустят за хорошее поведе- } \\
\text { ние, вкусно жрать там будет, вкусно пить ... Ну } \\
\text { зачем ему столько денег, он их что с собой в гроб } \\
\text { положит? Воровство чиновников может побе- } \\
\text { дит только банальный животный страх за кого } \\
\text { то из близких ему людей мать, жену, детей } \\
\text {..сложившаяся система себя не оправдала, более } \\
\text { того скомпроментировала уже дальше некуда! } \\
\text { Иначе никак. Всем спасибо.... (комментарий к по- } \\
\text { сту «Убытки Газпрома поделят на всех Россиян», } \\
\text { МВП) }\end{array}$ & $\begin{array}{l}\text { Лексические единицы с } \\
\text { оценочной семантикой, } \\
\text { разговорные слова и вы- } \\
\text { ражения, личные место- } \\
\text { имения } 1 \text { л. ед. ч., лич- } \\
\text { ные формы глагола, во- } \\
\text { просительные и воскли- } \\
\text { цательные конструкции }\end{array}$ \\
\hline
\end{tabular}

Доминирующими стратегиями адресата являются самопрезентационная и аргументативная. Самопрезентационная стратегия реализуется набором тактик, которые распределены примерно в равном процентном соотношении. Данная стратегия представлена тактиками солидаризирующей / отрицательной идентификации с адресантом и участниками сообщества, предъявление субъективной позиции, противопоставления общему оппоненту. Аргументирование осуществляется, как правило, посредством апелляции к этическим и эмоциональным доводам. Фатическая стратегия актуализируется адресатом большей частью в форме солидаризирующей похвалы адресанту, консолидирующего призыва / обращения к членам сообщества или посредством эксплицитного вовлечения в дискуссию.

\section{Заключение}

Динамика состава сообществ соцсетей на основе критерия «прирост за месяц» в иссле- дуемой выборке показывает в целом низкую активность протестной аудитории. При этом только половина мобилизационных постов из нашей выборки демонстрирует высокий и очень высокий индекс вовлеченности аудитории, который отражает выраженное в \% отношение количества реакций на публикацию к количеству подписчиков. Данный показатель является наиболее релевантным при оценке эффективности мобилизационного контента. Полученные результаты линейной регрессии подтверждают высокий коэффициент вовлеченности ряда постов, при этом регрессионный анализ не выявил зависимости между количественными показателями текста и коэффициентом его вовлеченности, что, по нашему мнению, является косвенным доказательством зависимости мобилизационного потенциала поста от качественных характеристик текста, а именно: способов экспликации адресанта, реализации определенных стратегий и тактик, особенностей текстовой структуры, использованных языковых средств. Названные каче- 
ственные характеристики текста согласуются со следующими установленными параметрами коллективно-личностного измерения протестной коммуникации, а именно: способами дискурсивного конструирования идентичности адресанта и адресата; коммуникативными стратегиями и тактиками, коммуникативными аспектами солидаризации участников общения.

В коммуникативном поведении адресанта доминирует аргументативная стратегия, реализуемая в первую очередь обращением к специально отобранным фактам с целью вызвать негативную протестную реализацию адресанта, а также к этическим и эмоциональным доводам; фатическая стратегия адресанта чаще всего актуализируется в консолидирующих призывах к сообществу; самопрезентация объективизируется преимущественно за счет идентификации с адресатом и противопоставления неодобряемому оппоненту.

Коммуникативное поведение адресата объективирует самопрезентационная и аргументативная стратегии, которые представлены тактиками предъявления.

Среди языковых средств, реализующих выделенные тактики, следует назвать общественно-политическую терминологию, пейоративную и мелиоративную лексику, конструкции экспрессивного синтаксиса.

Полученные результаты исследования феномена конфликтной мобилизации в социальных сетях позволяют составить прогнозы развития данного явления и предоставляют дополнительный материал для совершенствования процессов управления конфликтным социумом.

В рамках описанных стратегий тактики реализуются средствами разных языковых уровней. Следует выделить лексические, морфологические средства, а также элементы экспрессивного синтаксиса: парцеллированные, присоединительные, вставные вопросноответные конструкции, цепочки восклицательных, вопросительных предложений, стилистически маркированные конструкции-лозунги со значением «протестовать против чего-либо».

\section{ПРИМЕЧАНИЕ}

${ }^{1}$ Исследование выполнено при финансовой поддержке РФФИ в рамках научного проекта № 20-012-00193 «Протестная коммуникация в со- временном информационном пространстве России и Германии».

The reported study was funded by RFBR, project number 20-012-00193 "Protest communication in the modern information space of Russia and Germany".

\section{СПИСОК ЛИТЕРАТУРЫ}

Бараш Р. Э., Антоновский А. Ю., 2018. Системно-коммуникативное исследование радикальных движений, или как возможна научная теория протеста // Философский журнал. Т. 11, № 2. С. 91105. DOI: 10.21146/2072-0726-2018-11-2-91-105.

Бараш Р. Э., Антоновский А. Ю., 2019. Современная протестная коммуникация в контексте системно-коммуникативного подхода // Коммуникации. Медиа. Дизайн. Т. 4, № 3. С. 140-164.

Ваньке А. В., Ксенофонтова И. В., Тартаковская И. Н., 2014. Интернет-коммуникации как средство и условие политической мобилизации в России (на примере движения «За честные выборы») // Интеракция. Интервью. Интерпретация. Т. 6, № 7. С. 44-73.

Гладченко И. А., 2019. Новые подходы к изучению мобилизации в сетевых сообществах // Научнотехнические ведомости СПбГПУ. Гуманитарные и общественные науки. Т. 10, № 2. С. 3043. DOI: $10.18721 /$ JHSS.10203.

Киняшева Ю. Б., 2018. Социальные сети как инструмент политической мобилизации граждан в современной России // Известия Тульского государственного университета. Гуманитарные науки. № 3. С. 3-10.

Курбатов В. И., Крупенникова Л. Ш., 2016. Ракурсы социологического исследования сетевых сообществ // Гуманитарий Юга России. Т. 19, № 3. C. 50-58.

Милованова М. В., Терентьева Е. В., 2020. Русскоязычные политические блоги как актуальная практика протестной коммуникации: системно-коммуникативные измерения // Научный диалог. № 6. С. 101-116. DOI: 10.24224/22271295-2020-6-101-116.

Новые социальные движения в сетевую эпоху: статьи, интервью, экспертные заключения : монография, 2020. М. : Русское общество истории и философии наук. $282 \mathrm{c.}$

Пильгун М. А., 2018. Психолингвистический анализ медиаконтента в мультимодальном аспекте: протестные коммуникации \& большие данные // Вопросы психолингвистики. № 2 (36). C. 99-117. DOI: 10.30982/2077-5911-2-99-117.

Ребрина Л. Н., Шамне Н. Л., 2020. Системно-коммуникативные измерения современного протеста (на материале немецкоязычных онлайн- 
петиций) // Научный диалог. № 3. С. 151-167. DOI: 10.24224/2227-1295-2020-3-151-167.

Ребрина Л. Н., 2021. Конфликтная мобилизация в сообществах социальных сетей как актуальная практика протестной коммуникации: коллективно-личностное измерение // Научный диалог. № 5. C. 115-139. DOI: https://doi.org/ 10.24224/2227-1295-2021-5-115-139.

Филиппов И. Б., 2020. Количественные текстовые характеристики как фактор успешности продвижения публикаций в рамках протестной коммуникации в социальных сетях // Контуры глобальных трансформаций: политика, экономика, право. Т. 13, № 2. С. 249-268.

Шерстобитов А. С., Брянов К. А., 2013. Технологии политической мобилизации в социальной сети «ВКонтакте»: сетевой анализ протестного и провластного сегментов // Исторические, философские, политические и юридические науки, культурология и искусствоведение. Вопросы теории и практики. № 10 (36), ч. 1. С. 196-202.

Юрина И. А., Бородулина Н. Ю., Макеева М. Н., 2017. Исследование социальных сетей в контексте лингвистики новых медиа // Филологические науки. Вопросы теории и практики. № 11 (77), ч. 2. С. 178-181.

Яницкий О. Н., 2012. Массовая мобилизация: проблемы теории // Социс. № 6 (338). С. 3-12.

Cammaerts B., 2012. Protest Logics and the Mediation Opportunity Structure // European Journal of Communication. № 27. P. 117-134. URL: https://www.researchgate.net/ publication /254089297_ Protest_Logics_ and_the_Mediation_Opportunity_ Structure8 (date of access: 21.01.2021).

Cammaerts B., 2015. Social Media and Activism // The International Encyclopedia of Digital Communication and Society. The Wiley BlackwellICA International Encyclopedias of Communication Series / ed. by R. Mansell, P. Hwa. Oxford: Wiley-Blackwell. P. 1027-1034.

Castells M., 2009. Communication Power. Oxford : Oxford University Press. 571 p.

Castells M., 2012. Networks of Outrage and Hope. Social Movements in the Internet Age. Cambridge : Polity Press. 298 p.

Della Porta D. and Diani, 2006. Social Movements: An Introduction. $2^{\text {nd }}$ ed. Madlen, MA : Blackwell. 345 p.

Kavanaugh A. et al., 2017. Media Use by Young Tunisians During the 2011 Revolution vs 2014 Elections // Information Polity. № 22. P. 137-158. DOI: 10.3233/IP-170412.

Oniszczuk Z., 2011. Mediatisation of Politics and Politicisation of the Media. Two Dimensions of the Relationship // Studiów Medioznawczych. № 4 (47). P. 1-15.

\section{ИСТОЧНИКИ}

$E K$ - Ешкин Крот. URL: https://vk.com/eshkin_krot (дата обращения: 21.01.2021).

ЛФ - Левый фронт. URL: https://vk.com/leftfront (дата обращения: 25.01.2021).

MBП - Международная военная политика. URL: https://vk.com/military_press (дата обращения: 22.01.2021).

$O$ - Оппозиция. URL: https://vk.com/ruopp (дата обращения: 02.02.2021).

$O P Ф$ - Оппозиция РФ. URL: https://vk.com/ oppositionofrussia (дата обращения: 11.01.2021).

ПП-Против поправок. URL: https://www.instagram. com/protivpopravok (дата обращения: 18.01.2021).

ПС-Против системы. URL: https://vk.com/protiv_ sistems (дата обращения: 21.01.2021).

РБЦ - Россия без цензуры URL: https://vk.com/ russiauncensored (дата обращения: 21.01.2021).

РП - Родина погибает что будем делать? URL: https://vk.com/club17482011 (дата обращения: 11.01.2021).

РППВ - Россия против повышения пенсионного возраста. URL: https://vk.com/nopensionreform (дата обращения: 21.01.2021).

CTC-Статистика сообществ. URL: https:/allsocial. ru/communiti (дата обращения: 30.04.2021).

ЯВП - Я выступаю против. URL: https:/vk.com/ rusrise (дата обращения: 11.01.2021).

ЯПКР - Я против поправок к Конституции России. URL: https://vk.com/propokon (дата обращения: 30.01.2021).

$H R$ - Human Rights. URL: https://vk.com/ pravachelovekapro (date of access: 11.01.2021).

$S N$ - Я против нового срока мэра Собянина. URL: https://ru-ru.facebook.com/groups/SobianinNet/ (дата обращения: 21.01.2021).

\section{REFERENCES}

Barash R.E., Antonovskiy A.Yu., 2018. Sistemnokommunikativnoe issledovanie radikalnykh dvizheniy, ili kak vozmozhna nauchnaya teoriya protesta [A Study of Social Movements From the Systemic Communication Standpoint: Is a Scientific Theory of Political Protest Possible?]. Filosofskiy zhurnal [Philosophy Journal], vol. 11, no. 2, pp. 91-105. DOI: 10.21146/20720726-2018-11-2-91-105.

Barash R.E., Antonovskiy A.Yu., 2019. Sovremennaya protestnaya kommunikatsiya $\mathrm{v}$ kontekste sistemno-kommunikativnogo podkhoda [Contemporary Protest Communication in the Context of a System-Communicative Approach]. 
Kommunikatsii. Media Dizayn [Communications. Media. Design], vol. 4, no. 3, pp. 140-164.

VankeA.V., Ksenofontova I.V., Tartakovskaya I.N., 2014. Internet-kommunikatsii kak sredstvo i uslovie politicheskoy mobilizatsii v Rossii (na primere dvizheniya «Za chestnye vybory») [Internet Communication as a Means and a Condition of Political Mobilization in Russia: Case of the «For Fair Elections»]. Interaktsiya. Intervyu. Interpretatsiya [Interaction. Interview. Interpretation], vol. 6, no. 7, pp. 44-73.

Gladchenko I.A., 2019. Novye podkhody k izucheniyu mobilizatsii v setevykh soobshchestvakh [New Approaches for Studying Mobilization in Network Communities]. Nauchno-tekhnicheskie vedomosti SPbGPU [St. Petersburg State Polytechnical University Journal. Humanities and Social Sciences], vol. 10, no. 2, pp. 30-43. DOI: $10.18721 / \mathrm{JHSS} .10203$.

Kinyasheva Yu.B., 2018. Sotsialnye seti kak instrument politicheskoy mobilizatsii grazhdan $\mathrm{v}$ sovremennoy Rossii [Social Networks As a Tool for Political Mobilization of Citizens in Modern Russia]. Izvestiya Tulskogo gosudarstvennogo universiteta. Gumanitarnye nauki [Izvestiya Tula State University], no. 3, pp. 3-10.

Kurbatov V.I., Krupennikova L.Sh., 2016. Rakursy sotsiologicheskogo issledovaniya setevykh soobshchestv [The Foreshortenings of Sociological Research of Net-Communities in the Internet]. Gumanitariy Yuga Rossii [Humanities of the South of Russia], vol. 19, no. 3, pp. 50-58.

Milovanova M.V., Terenteva E.V., 2020. Russkoyazychnye politicheskie blogi kak aktualnaya praktika protestnoy kommunikatsii: sistemno-kommunikativnye izmereniya [Russian Political Blogs As Relevant Practice of Protest Communication: Systemic-Communicative Dimensions]. Nauchnyy dialog [Nauchnyi dialog], no. 6, pp. 101-116. DOI: 10.24224/22271295-2020-6-101-116.

Novye sotsialnye dvizheniya $\mathrm{v}$ setevuyu epokhu: stat'i, interv'yu, ekspertnye zaklyucheniya: monografiya [New Social Movements in the Network Age: Articles, Interviews, Expert Opinions. Monograph], 2020. Moscow, Russkoe obshchestvo istorii i filosofii nauk Publ. 282 p.

Pilgun M.A., 2018. Psikholingvisticheskiy analiz mediakontenta $\mathrm{v}$ mul'timodal'nom aspekte: protestnye kommunikatsii \& bolshie dannye [Psycholinguistic Analysis of the Media Content in the Multimodal Aspect: Protest Communications \& Big Data]. Voprosy psikholingvistiki [Journal of Psycholinguistics], no. 2 (36), pp. 99-117. DOI: 10.30982/2077-5911-299-117.
Rebrina L.N., Shamne N.L., 2020. Sistemnokommunikativnye izmereniya sovremennogo protesta (na materiale nemetskoyazychnykh onlayn-petitsiy) [Systemic-Communicative Dimensions of Modern Protest (Based on German-Language Online Petitions)]. Nauchnyy dialog [Nauchnyi Dialog], no. 3, pp. 151-167. DOI: 10.24224/2227-1295-2020-3-151-167.

Rebrina L.N., 2021. Konfliktnaya mobilizatsiya v soobshchestvakh sotsialnykh setey kak aktual'naya praktika protestnoy kommunikatsii: kollektivno-lichnostnoe izmerenie [Conflict Mobilization in Social Networks Communities as an Actual Practice of Protest Communication: Collective-Personal Dimension]. Nauchnyy dialog [Nauchnyi Dialog], no. 5. pp. 115-139. DOI: https:// doi.org/10.24224/2227-1295-2021-5-115-139.

Filippov I.B., 2020. Kolichestvennye tekstovye kharakteristiki kak faktor uspeshnosti prodvizheniya publikatsiy v ramkakh protestnoy kommunikatsii $\mathrm{v}$ sotsial'nykh setyakh [Quantitative Indicators of Text Style As a Factor of the Post Promotion in a Social Media Protest Communication]. Kontury global'nykh transformatsiy: politika, ekonomika, parvo [Outlines of Global Transformations: Politics, Economics, Law], vol. 13, no. 2, pp. 249-268.

Sherstobitov A.S., Bryanov K.A., 2013. Tekhnologii politicheskoy mobilizatsii $\mathrm{v}$ sotsialnoy seti «VKontakte»: setevoy analiz protestnogo i provlastnogo segmentov [Political Mobilization Technologies in Social Network "VKontakte": Network Analysis of Protest and Pro-Regime Segments]. Istoricheskie, filosofskie, politicheskie $i$ yuridicheskie nauki, kulturologiya $i$ iskusstvovedenie. Voprosy teorii i praktiki [Historical, Philosophical, Political and Law Sciences, Culturology and Study of Art. Issues of Theory and Practice], no. 10 (36), part 1,pp. 196-202.

Yurina I.A., Borodulina N.Yu., Makeeva M.N., 2017. Issledovanie sotsial'nykh setey $\mathrm{v}$ kontekste lingvistiki novykh media [Study of Social Networks in the Context of New Media Linguistics]. Filologicheskie nauki. Voprosy teorii i praktiki [Philology. Theory \& Practice], no. 11 (77), part 2, pp. 178-181.

Yanitskiy O.N., 2012. Massovaya mobilizatsiya: problemy teorii [Mass Mobilization: Issues of Theory]. Sotsis, no. 6(338), p. 3-12.

Cammaerts B., 2012. Protest Logics and the Mediation Opportunity Structure. European Journal of Communication, no. 27, pp. 117-134. URL: https://www.researchgate.net/publication/ 254089297_Protest_Logics_and_the Mediation_Opportunity_Structure8 (accessed 21 January 2021). 


\section{МАТЕРИАЛЫ И СООБЩЕНИЯ}

Cammaerts B., 2015. Social Media and Activism. Mansell R., Hwa P., eds. The International Encyclopedia of Digital Communication and Society. The Wiley Blackwell-ICA International Encyclopedias of Communication series. Oxford, Wiley-Blackwell, pp. 1027-1034.

Castells M., 2009. Communication Power. Oxford, Oxford University Press. $571 \mathrm{p}$.

Castells M., 2012. Networks of Outrage and Hope. Social Movements in the Internet Age. Cambridge, Polity Press. 298 p.

Della Porta D., Diani, M. 2006. Social Movements: An Introduction. Madlen, MA, Blackwell. $345 \mathrm{p}$.

Kavanaugh A. et al., 2017. Media Use by Young Tunisians During the 2011 Revolution vs 2014 Elections. Information polity, no. 22, pp. 137 158. DOI: $10.3233 /$ IP-170412.

Oniszczuk Z., 2011. Mediatisation of Politics and Politicisation of the Media. Two Dimensions of the Relationship. Studiów Medioznawczych, no. 4 (47), pp. 1-15.

\section{SOURCES}

Eshkin Krot. URL: https://vk.com/eshkin_krot (accessed 21 January 2021).

Levyy front. URL: https://vk.com/leftfront (accessed 25 January 2021).
Mezhdunarodnaya voennaya politika. URL: https:// vk.com/military_press (accessed 22 January 2021).

Oppozitsiya. URL: https://vk.com/ruopp (accessed 2 February 2021).

Oppozitsiya RF. URL: https://vk.com/ oppositionofrussia (accessed 11 January 2021).

Protiv popravok. URL: https://www.instagram.com/ protivpopravok (accessed 18 January 2021).

Protiv sistemy. URL: https://vk.com/protiv_sistems (accessed 21 January 2021).

Rossiya bez tsenzury. URL: https://vk.com/ russiauncensored (accessed 21 January 2021).

Rodina pogibaet chto budem delat? URL: https:// vk.com/club17482011 (accessed 11 January 2021).

Rossiya protiv povysheniya pensionnogo vozrasta. URL: https://vk.com/nopensionreform (accessed 21 January 2021).

Statistika soobshchestv. URL: https://allsocial.ru/ communiti (accessed 30 April 2021).

Ya vystupayu protiv. URL: https://vk.com/rusrise (accessed 11 January 2021).

Ya protiv popravok $k$ Konstitutsii Rossii. URL: https:// vk.com/propokon (accessed 30 January 2021).

Human Rights. URL: https://vk.com/pravachelovekapro (accessed 11 January 2021).

Ya protiv novogo sroka mera Sobyanina. URL: https:// ru-ru.facebook.com/groups/SobianinNet (accessed 21 January 2021).

\section{Information About the Authors}

Marina V. Milovanova, Doctor of Sciences (Philology), Professor, Department of Russian Philology and Journalism, Volgograd State University, Prosp. Universitetsky, 100, 400062 Volgograd, Russia, mv_milovanova@volsu.ru, https://orcid.org/0000-0002-6198-6972

Elena V. Terentyeva, Doctor of Sciences (Philology), Associate Professor, Professor, Department of Russian Philology and Journalism, Volgograd State University, Prosp. Universitetsky, 100, 400062 Volgograd, Russia, ev_terenteva@volsu.ru, https://orcid.org/0000-0003-3589-4879

\section{Информация об авторах}

Марина Васильевна Милованова, доктор филологических наук, профессор кафедры русской филологии и журналистики, Волгоградский государственный университет, просп. Университетский, 100, 400062 г. Волгоград, Россия, mv_milovanova@volsu.ru, https://orcid.org/0000-0002-6198-6972

Елена Витальевна Терентьева, доктор филологических наук, доцент, профессор кафедры русской филологии и журналистики, Волгоградский государственный университет, просп. Университетский, 100, 400062 г. Волгоград, Россия, ev_terenteva@volsu.ru, https://orcid.org/0000-0003-3589-4879 